\title{
EVALUATION OF ANXIETY LEVELS AND SATISFACTION RATES IN PATIENTS WHO UNDERWENT LAPAROSCOPIC CHOLECYSTECTOMY WITH VIDEO CONSENT
}

\author{
VİDEO ONAM ALINARAK LAPAROSKOPİK KOLESISTEKTOMI UYGULANAN HASTALARDA \\ ANKSIYYETE VE MEMNUNIYET DÜZEYLERINIIN DEĞERLENDİRILMESİ
}

Yunus DÖNDER ${ }^{1}$, Ömer TOPUZ ${ }^{1}$, Saliha KARAGÖZ EREN ${ }^{1}$, Ramazan AZAR ${ }^{2}$, Tamer ERTAN ${ }^{1}$, Yusuf SEVIM ${ }^{1}$

\section{ABSTRACT}

AIM:It is thought that explaining the video of the surgery to be applied to the patient by the surgeon performing the operation will reduce anxiety and increase satisfaction. In this study, it was aimed to compare the anxiety and satisfaction rates between the video and verbal consent groups.

MATERIAL AND METHOD: The study was planned as a prospective randomized. The patients were divided into two groups as video consent and verbal consent. The surgical procedure and possible complications were explained to the video consent group by watching the surgery video. Verbal information was given to the other group as routinely. The Amsterdam anxiety scale was applied to the patients on the morning of the surgery and their anxiety levels were measured. Postoperative visual analog scale were measured at 3., 8., and 24 th hours. Satisfaction score questionnaire was applied to both groups in the postoperative 1st month.

RESULTS: 53 patients participated in the study. 13 patients were excluded from the study. Sixteen $(40 \%)$ of the 40 patients included in the study were male. The Amsterdam anxiety scale score was significantly lower in the video informed group than in the verbally informed group $(p<0.05)$. When the pain was evaluated with a visual analog scale, the results did not differ significantly between the groups ( $p>0.05)$. When each group was compared within itself, it was observed that the pain was less at the 24th hour $(<0.05)$.

CONCLUSION: In this study, it was observed that the patients in the group whose video consent was obtained had less anxiety. There was no significant difference between the pain levels between the two groups. With the increase of such studies, it is thought that surgical consent can be obtained in the form of video consent in the near future.

Keywords: Cholecystectomy, Cholelithiasis, Informed consent, Video informed consent

\section{ÖZET}

AMAÇ: Hastaya uygulanacak ameliyatın videosunu, ameliyatı yapan cerrah tarafindan anlatmanın kaygıyı azaltacağ 1 ve memnuniyeti artıracağı düşünülmektedir. Bu çalışmada da video ve sözlü onam grupları arasında kaygı ve memnuniyet oranlarının karşılaştırılması amaçlanmıştır.

GEREÇ VE YÖNTEM: Çalışma prospektif randomize olarak planlandı. Hastalar video onam ve sözel onam olmak üzere iki gruba ayrıldı. Video onam grubuna cerrahi işlem ve gelişebilecek komplikasyonlar, ameliyat videosu izletilerek anlatıldı. Diğer gruba rutinde uygulandığı gibi sözlü olarak bilgi verildi. Hastalara ameliyat sabahı Amsterdam anksiyete ölçeği uygulanarak anksiyete düzeyleri ölçüldü. Postoperatif dönemde visuel analog skala ile 3.,8. ve 24. saatlerde ağrı düzeyleri ölçüldü. Postoperatif 1 . ayda her iki gruba da memnuniyet skoru anketi uygulandi.

BULGULAR: Calısmaya 53 hasta katıldı. Calısmaya dahil edilen 40 hastanın 16 (\%40) si erkek, 24 (\%60) ü kadındı. Video ile bilgilendirilmiş grupta Amsterdam anksiyete ölçeği puanı, sözlü bilgilendirilmiş gruba göre anlamlı olarak düşüktü ( $\mathrm{p}<0.05)$. Ağrı, visuel analog skala ile değerlendirildiğinde sonuçlar gruplar arasında anlamlı farklılık göstermezken ( $p>0.05$ ), her grup kendi içinde karşılaştırıldığında 24. saatte ağrının daha az olduğu görüldü $(<0.05)$.

SONUÇ: $\mathrm{Bu}$ çalışmada video onam alınan gruptaki hastaların anksiyetelerinin daha az olduğu görüldü. İki grup arasındaki ağrı düzeyleri arasında anlamlı fark tespit edilemedi. Bunun gibi çalışmaların artmasıyla yakın gelecekte ameliyat onamlarının video onam şeklinde alınabileceği düşünülmektedir.

Anahtar Kelimeler: Kolesistektomi; Kolelithiazis; Sözel bilgilendirilmiş onam; Video bilgilendirilmiș onam

\section{${ }^{1}$ Sağlık Bilimleri Üniversitesi, Kayseri Şehir Eğitim ve Araştırma Hastanesi, Genel Cerrahi Kliniği, Kayseri, Türkiye}

${ }^{2}$ Muş Devlet Hastanesi, Genel Cerrahi Kliniği, Muş, Türkiye

Geliş Tarihi / Submitted : Nisan 2021 / April 2021

\footnotetext{
Sorumlu Yazar / Corresponding Author:

Yunus DÖNDER

Kayseri Şehir Hastanesi, Genel Cerrahi Kliniği, Şeker Mah. Muhsin Yazıcıoğlu Bulvarı No:77 38080, Kocasinan, Kayseri, Türkiye

Phone : +905325848541 Fax : +903523157986

E-mail: ydonder@hotmail.com
}

Kabul Tarihi / Accepted : Haziran 2021 / June 2021

\author{
Yazar Bilgileri /Author Information: \\ Yunus DÖNDER (ORCID: 0000-0002-0560-1708), \\ Ömer TOPUZ (ORCID: 0000-0001-8086-4682) E-mail : drotopuz@yahoo.com, \\ Saliha KARAGÖZ EREN (ORCID: 0000-0003-4114-6578) E-mail : salihakaragozeren@hotmail.com, \\ Ramazan AZAR (ORCID: 0000-0002-3850-7486) E-mail : ramazanazar@hotmail.com, \\ Tamer ERTAN（ORCID:0000-0003-3721-2253） E-mail : tertan70@hotmail.com, \\ Yusuf SEVIM (ORCID: 0000-0002-2708-1598) E-mail : yusufsevim@gmail.com
}




\section{INTRODUCTION}

Consent form is the contract between the patient and the physician. In this contract, both parties should express themselves well. In surgical procedures, patients and their relatives are sufficiently informed about the procedure. While surgeons try to inform patients sufficiently due to their responsibilities, they can use various arguments such as pictures they draw, photos and videos. The necessity of the informing process covers what can happen if it is not done, how to do it and the complications that will be encountered when done. Patients can comment according to their education level. While some of the patients who previously researched the procedure are over-feared, some patients may not be able to understand the severity of the procedure. The Internet, which has been increasingly used in recent years, has positive and negative consequences in the health sector as well as in every field (1). Easily accessible edited videos may not reflect the process clearly enough. Due to the adequate and clear information given to the patient, the patient knows that he / she may have pain in the postoperative process or where the complication arises and how to solve it if a complication related to the procedure is observed. Thus, anxiety in the process decreases with the healthy communication that the patient makes with the surgeon. Surgeons doing the same job may or may not be able to provide the same information about the same surgeries. Therefore, surgeons who will perform the same procedure in the future may watch the same videos and get approval. We aimed to evaluate the preoperative anxiety and satisfaction in the postoperative period between the verbal consent and video consent groups.

\section{MATERIAL AND METHOD Study Design}

The study was planned as a prospective randomized. Ethics committee approval was obtained from Erciyes University (date : 30.12.2019 no: 2019/878 ). Written consent of all participants was obtained. More patients were considered to participate in the study, but our hospital was declared a pandemic hospital due to the COVID-19 outbreak. Since elective and laparoscopic cases were stopped, the study was terminated early. A total of 40 patients were included in the study, which were divided into verbal and video consent group between 1 January 2020 and 1 May 2020. (As of March 10, 2020, elective cases have not been received). Inclusion criterias are between the ages of 18-65. Volunteer to participate in the study, to be literate, speak Turkish. No hearing, vision and speech loss. Exclusion criterias in the study are being under the age of 18 and over 65 years old, mental retardation, diagnosing psychiatric illness such as depression or obsessive compulsive disorder. Patients with Hospital Anxiety and Depression Scale (HADS) with anxiety score above 10, depression score above 7 , hearing, speech and vision loss, non-Turkish speaking and illiterate.

The patients were informed about the study the day before the operation. The patients who accepted to participate in the study were administered a Turkish validated HADS $(2,3)$. Patients included in the study were divided into two groups by sealed envelop system. An informative talk of about 10 minutes was given to the verbal consent group about the routine surgery. Consent form was signed. In the video consent group, 8 minutes video about laparoscopic cholecystectomy surgery and complications of the operation were monitored then consent form was signed. The Amsterdam Preoperative Anxiety and Information Scale (APAIS), which was validated in Turkish on the morning of the operation, was performed $(4,5)$. VAS scores of the patients at the $3 \mathrm{rd}$, 8 th and 24th hours were evaluated after the operation. Daily drainage amount, whether complications developed or not were recorded. In the first postoperative month, $(0$ point were not satisfied, 5 points were very satisfied,) a satisfaction questionnaire was conducted.

\section{Statistical Analysis}

SPSS 23.0 package program was used for statistical analysis of the data. Categorical measurements were summarized as numbers and percentages, while continuous measurements weresummedas mean, deviation and minimum-maximum. The suitability of variables to normal distribution was examined using visual (histogram and probability plots) and analytical methods (Kolmogorov-Smirnov / ShapiroWilk Tests). Chi-square test and Fischer's precision test were used to compare categorical variables. Independent student t-test was used for parameters that fit normally, and Mann Whitney $U$ tests were used in groups that did not fit the normal distribution. Paired sample t-test was applied for differences in vas scores. $\mathrm{p}<0.05$ will be considered significant.

\section{RESULTS}

Patients who applied to the general surgery clinic of our hospital and planned for cholecystectomy were divided into two groups as verbal consent and video consent. HADS was performed to the patients when the operation decision was taken. In the HADS, 12 patients with anxiety score above 10 and depression score above 7 excluded in the study. After passing the HADS, one of our patients who volunteered to participate in the study was excluded from the study because the patient did not want to watch videos, although she was selected to the video consent group with a closed envelope method. While more patients were considered to be included in the study, the study was terminated early since our hospital was chosen as a pandemic hospital in the COVID-19 pandemic. A total of 40 patients were included in the study, of which $16(40 \%)$ were male and 24 were female $(60 \%)$. As summarized in Table 1, the gender, age, HADS and satisfaction score of the patients and the differences between the groups were not statistically significant ( $p>0.05$ ). In addition, VAS scores (3rd, 8th, and 24th hours) did not differ between the two groups. Analgesics were applied to both groups at the same doses in our routine application.

APAIS is high in verbal consent group and was found to be statistically significant in patients who received verbal consent compared to those who received video consent $(\mathrm{p}<0.05)$. 
When the differences between the VAS 3rd hour, 8th hour and 24th hour findings between the groups were examined; While no significant difference was observed between the two groups, when each group was evaluated within itself, the differences between the VAS findings at the 3rd Hour and the 24th Hour were statistically significant (Table 2) $(\mathrm{p}<0.05)$.

\section{DISCUSSION}

Access to information has become easier today in every field, and the risk of accessing uncorrect information has increased. In order to prevent information pollution, we believe that standardized information will be appropriate in the field of health as well as in every field. The incident that led us to this study was that some of the patients were misinformed and exposed to information pollution, while some patients were not aware of the seriousness of the surgical procedure they would undergo. Therefore, some of the patients have serious anxiety, and some others may overreact because of not being aware of the importance and risks of the surgical procedure, especially in case of complications. Reduced anxiety was shown in medically informed patients with watching youtube operation videos (6). Considering that patients may not be able to understand the videos they watch, we think that it is more effective to watch videos by being told by a specialist.

It is thought that videos related to each disease may be created in the future by the relevant associations, in order to achieve a certain standardization. Surgeons may not provide sufficient information including the patients' questions about the surgical procedure because of workload. Providing sufficient information and time for discussion about the disease with the patient is also important for medicolegal conditions. In a study, less medicolegal problems were experienced with sufficiently informed patients (7). Although visual information is thought to take a long time, a study by J. Zieren et al. showed shorter time spent in informing the procedure with video clips (8).

In a prospective cohort study about cervical hernias, patients were divided into two groups; verbally informed patient group $(n=124)$, and the video informed group $(n=63)$. The subjects were evaluated with a 14-question test, and the correct response rate was found to be significantly higher in the video informed group (9).

Using visual materails (e.g. video clips, surgical photographs, simulation) to inform patients about the surgical procedure increases the the patients' satisfaction. In a dermatology study, 84 patients undergoing skin biopsy were divided into verbally or video-asssisted informed groups. The patients in video-assisted group had significant higher satisfaction scores compared to verbally informed group. The authors emphasized that medicolegal problems

Table 1 : Demographic data and test results. $\mathbf{p}<0,05$, Pearson Chi-square, Independent student t-test, Mann whitney u test. ( SD : standart deviation, HADS : The hospital anxiety and depression scale, APAIS : The Amsterdam preoperative anxiety and information scale, VAS : Visual analogue scale)

\begin{tabular}{|c|c|c|c|c|}
\hline & & & \multirow[b]{2}{*}{$\mathbf{P}$} \\
\hline & & $\begin{array}{c}\text { Verbal consent(n: } 22) \\
n(\%)\end{array}$ & $\begin{array}{c}\text { Video consent(n: 18) } \\
\text { n(\%) }\end{array}$ & \\
\hline \multirow{4}{*}{ Gender } & Man & $9(40,9)$ & $7(38,9)$ & \multirow{2}{*}{0,897} \\
\hline & Woman & $13(59,1)$ & $11(61,1)$ & \\
\hline & & $\begin{array}{l}\text { Verbal consent } \\
(\mathrm{n}: 22)\end{array}$ & $\begin{array}{l}\text { Video consent } \\
\text { (n: 18) }\end{array}$ & \multirow{2}{*}{$\mathbf{P}$} \\
\hline & & Mean \pm SD & Mean \pm SD & \\
\hline Age & $50,45 \pm 11,59$ & $48,88 \pm 11,46$ & 0,672 & Age \\
\hline HADS (anxiety score) & $5,86 \pm 2,64$ & $6,27 \pm 2,29$ & 0,639 & HADS (anxiety score) \\
\hline $\begin{array}{l}\text { HADS (depression } \\
\text { score) }\end{array}$ & $5,27 \pm 2,25$ & $5,44 \pm 1,65$ & 0,911 & $\begin{array}{l}\text { HADS (depression } \\
\text { score) }\end{array}$ \\
\hline APAIS & $18,72 \pm 2,93$ & $11,66 \pm 3,91$ & 0,000 & APAIS \\
\hline VAS 3 th hour & $6,7 \pm 1,31$ & $7,05 \pm 1,34$ & 0,539 & VAS 3 th hour \\
\hline VAS 8 th hour & $4,54 \pm 1,37$ & $4,44 \pm 1,09$ & 0,596 & VAS 8 th hour \\
\hline VAS 24 th hour & $3,04 \pm 1,46$ & $2,55 \pm 0,61$ & 0,215 & VAS 24 th hour \\
\hline Satisfaction score & $4,59 \pm 0,59$ & $4,61 \pm 0,60$ & 0,871 & Satisfaction score \\
\hline
\end{tabular}

Table 2 : Evaluation of VAS scores in each group at the 3rd and 24th hours (VAS : Visual analogue scale). Paired Samples t-test.

\begin{tabular}{|c|c|c|c|c|}
\hline Group & & $\mathbf{N}$ & Mean \pm SD & p \\
\hline \multirow{2}{*}{ Group 1} & VAS 3 th hour & 22 & $6,72 \pm 1,31$ & \multirow{2}{*}{0,000} \\
\hline & VAS 24 th hour & 22 & $3,04 \pm 1,46$ & \\
\hline \multirow{2}{*}{ Group 2} & VAS 3 th hour & 18 & $7,05 \pm 1,34$ & \multirow{2}{*}{0,000} \\
\hline & VAS 24 th hour & 18 & $2,55 \pm 0,61$ & \\
\hline
\end{tabular}


could be encountered with insufficient information (10).

Written and signed informed consent should be obtained from patients, and this is as much importance as surgery (11). Treatment procedures, which are being more complex increasingly with development of technology, can be difficult for patients to understand. In a study of 93 patients, a short 2-minute video about minimally invasive vascular surgery procedures was prepared. It was seen that the patients who watched this video were easier to understand the procedure to be applied to them and their satisfaction after the surgery was increased (11).

In a hospital in Switzerland, a prospective study was carried out with the participation of 52 patients in the Neurosurgical department. In this web-based audovisual patient information study, $84 \%$ of the patients stated that they understood better with this system, $90 \%$ asked for such videos to be prepared for other surgical procedures, and $86 \%$ stated that they would recommend this system to others.

Written informed consent may differ between hospitals in the same region or even between countries. Webbased audovisual briefings have also been tried by various researchers. It has been observed that there are generally positive effects on patient satisfaction and anxiety. Oral and maxillofacial surgeons have performed a prospective cohort study to investigate the effect of the video information procedure on anxiety in the 3rd Molar tooth extraction, which has generally proved to be highly fearful and anxious. Unlike other studies, in this study, anxiety increased in $31 \%$ of patients, decreased only in $12 \%$, and no change in $57 \%$ (12).

As it is known, anxiety has negative effects on the immune system. The immune system has an important role in wound healing. In the next studies, the effects of the patients who watched videos can be investigated by studying the immunity. In our study, mostly data was collected through questionnaires. The APAIS questionnaire score was found significantly lower in the video consent group when performed on the morning of surgery. This was thought to be the result of rehearsing some kind of surgery of the patients (what will happen in the surgery, what difficulties can be encountered during the procedure and how to overcome these difficulties).

\section{CONCLUSION}

As a result, although there are studies claiming otherwise, we think that creating videos specific to the disease and informing the patients through these videos will contribute positively to the patient-physician relationship. We believe that this positive contribution will not only increase the patient's compliance to the surgery and reduce anxiety, but will also lead to less medico-legal problems.

Acknowledgments: We would like to thank Kayseri City Training and Research Hospital for its contribution to the general surgery clinic.

Authors' Contribition: YD: Literature search and writer. SKE: Fundings and analysis. OT: Conception and design. TE: Supervision and critical review. RA: Data collection and processing. YS: Interpretation

\section{REFERENCES}

1.)Lévêque $M$, Dimitriu $C$, Gustin $T$, et al. Evaluation of neurooncology information for French speaking patients on the Internet. Neurochirurgie. 2007;53:343-55

2.)Zigmond AS, Snaith RP. The hospital anxiety and depression scale. Acta psychiatrica scandinavica. 1983;67:361-70.

3.)Aydemir Ö, Guvenir T, Kuey L, et al. Validity and reliability of Turkish version of hospital anxiety and depression scale. Turk Psikiyatri Derg. 1997;8:280-87.

4.) Moerman N, van Dam FS, Muller MJ, et al. The Amsterdam preoperative anxiety and information scale (APAIS). Anesthesia \& Analgesia. 1996;82:445-51.

5.)Cetinkaya F, Kavuran E, Aslan KS. Validity and reliability of the Amsterdam Preoperative Anxiety and Information Scale in the Turkish population. Turkish journal of medical sciences. 2019;49:178-83.

6.) O'Connor $M$, Brennan $K$, Kazmerchak S, et al. "YouTube videos to create a "virtual hospital experience" for hip and knee replacement patients to decrease preoperative anxiety: a randomized trial." Interactive journal of medical research. 2016;5(2):e10.

7.)Bailey CS, Jennifer AB. "Claims of alleged medical negligence in refractive surgery: causes and avoidance." Contact Lens and Anterior Eye. 2007;30:144-47.

8.)Zieren J, Paul M, Menenakos C, et al. Videoinformationsfilm vor Leistenhernienoperationen. Der Chirurg. 2006;77:150-53.

9.)Lee YS, Cho DC, Sung JK, et al. "The Effect of an Educational and Interactive Informed Consent Process on Patients With Cervical Spondylotic Myelopathy Caused by Ossification of the Posterior Longitudinal Ligament." Spine. 2020;45:193-200. 10.)Armstrong AW, Alikhan A, Cheng LS et al. "Portable video media for presenting informed consent and wound care instructions for skin biopsies: a randomized controlled trial." British Journal of Dermatology. 2010;163:1014-19. 11.)Bowers N, Eisenberg E, Montbriant JJ, et al. "Using a multimedia presentation to improve patient understanding and satisfaction with informed consent for minimally invasive vascular procedures." The Surgeon. 2017;15:7-11. 12.)Laskin DM, Priest JH, Alfaqih S, et al. "Does viewing a third molar informed consent video decrease patients' anxiety?." Journal of Oral and Maxillofacial Surgery. 2018;76:2515-17. 